\title{
PRINSIP EQUALITY BEFORE THE LAW SEBAGAI ILLAT HUKUM DALAM QISHASHMENURUT AL-SYAFI'I DAN ABU HANIFAH
}

\author{
Riskiyanto Munawar \\ BRI Syariah, Sukabumi, Jawa Barat \\ Email : munawarriskiyanto@gmail.com
}

\begin{abstract}
In Islamic law, a deliberate act of murder is sanctioned with qishash according to Allah's SWT commandment in al-Quran Surah al-Baqarah verse 178. In its application, the Islamic Law scholars agree that if someone kills intentionally without any shar'i reasons, then the penalty is qishash. However there is a disagreement about sanctions for a Muslim who kills a non-muslim, whether the qishash is applied to this situation or not. Using a comparative descriptive method, the results show that the death penalty (qishash) according to al-Shafi'i can only be applied if both the perpetrator and victim are fellow Muslims, and qishash does not apply if the victim is a non-Muslim. His view is based upon dzahirnash. As for Abu Hanifa, it was argued that qishash was still carried out even though the victim was a dhimmi (a protected non-muslim), considering that Islamic law does not only apply to Muslims, but also to all human. This opinion is in line with the principle of equality before the law as applicable in Indonesia.
\end{abstract}

\section{Keywords:}

qishash, equality before the law, human rights

\begin{abstract}
Abstrak
Dalam Hukum Islam, tindakan pembunuhan yang disengaja disanksi dengan qishash sebagaimana firman Allah SAW dalam al-Quran surat al-Baqarah ayat 178. Dalam penerapannya, jumhur ulama sepakat, bahwa apabila seseorang membunuh dengan sengaja tanpa alasan yang dibenarkan syar'i, maka hukumannya adalah qishash. Namun mereka berbeda pendapat tentang sanksi bagi seorang muslim yang membunuh seorang kafir (dzimmi). Dengan menggunakan metode deskriptif komparatif, Hasil penelitian menunjukkan bahwa sanksi hukuman mati (qishash) menurut al-Syafi'i hanya dapat diterapkan apabila pelaku dan korban adalah sesama muslim, dan qishash tidak berlaku apabila korban seorang non-muslim karena adanya perbedaan keyakinan antara pembunuh dan yang dibunuh sebagaimana dzahir nash. Adapun Abu Hanifah berpendapat, bahwa qishah tetap dilakukan meskipun korban adalah seorang dzimmi, mengingat hukum Islam tidak hanya berlaku bagi umat muslim saja, namun juga bagi seluruh manusia. pendapat tersebut sejalan dengan asas persamaan dihadapan hukum sebagaimana yang berlaku di Indonesia.
\end{abstract}

Kata Kunci:

Qishash, persamaan dihadapan hukum, hak asasi manusia 


\section{Pendahuluan}

Di dalam ajaran Islam, ketentuan mengenai kejahatan manusia beserta tindakan baik berupa pencegahan maupun peanggulangannya dibahas dalam fiqh jinayah. ${ }^{1}$ Namun, mengacu pada bentuk hukuman seperti qishash, rajam, potong tangan, dera (jilid), menimbulkan kesan bahwa hukum Islam merupakan hukum yang kejam. Padahal apabila melihat sejarah hukum jinayah, jarang hukuman-hukuman tersebut diterapkan. Bahkan muncul fakta bahwa tidak semua tindak pidana (jarimah) diancam dengan hudud atau qishash, pada umumnya tindak pidana justru diancam dengan ta'zir, yaitu hukuman yang tidak ditetapkan syar'i. ${ }^{2}$ Qishash adalah hukuman yang diberikan terhadap orang yang melakukan tindak pidana pembunuhan dan melukai tubuh dengan sengaja. ${ }^{3}$

Pada dasarnya hukuman terhadap sebuah pelanggaran bukan berarti pembalasan, akan tetapi untuk mewujudkan dan memelihara lima sasaran pokok agama, yaitu jiwa, akal, kehormatan, keturunan, dan harta. ${ }^{4}$ Menjaga kelima hal pokok ini diyakini dapat mewujudkan kehidupan bahagia tidak hanya di dunia, namun juga di akhirat.. Firman Allah dalam surat al-Baqarah ayat 179 menyebutkan:

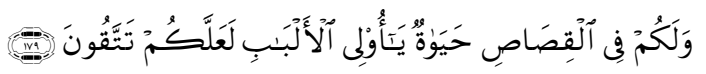

"Dan dalam qishash itu ada jaminan kelangsungan hidup bagimu, hai orang-orang yang berakal, supaya kamu bertaqwa".

Penerapan qishash tersebut menimbulkan pertanyaan, apakah ia dapat diterapkan kepada seorang muslim yang membunuh atau melukai seorang non-muslim. Mengingat terdapat catatan Al-Syafi'i dalam kitab al-Umm yang berbunyi:

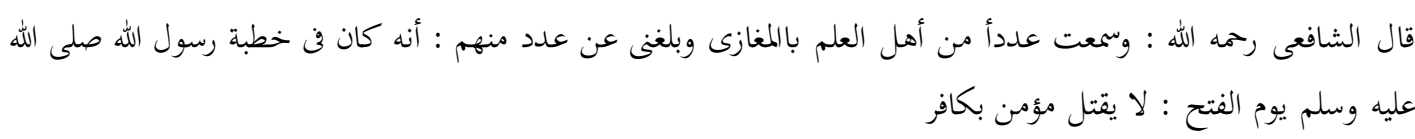

Al-Syafi'i berkata: "Dan saya mendengar beberapa orang dari ahli Maghazy dan sampai kepadaku dari bilangan mereka itu bahwa pada khutbah Rasulullah SAW pada hari penaklukan kota Makkah 'Tidak dibunuh mukmin atas kafir'."'5

Mengenai hal tersebut di atas, terdapat perbedaan pendapat antara al-Syafi'i dengan Abu Hanifah dalam pemberian sanksi terhadap pelaku pembunuhan non muslim, sehingga perbedaan tersebut perlu untuk dikaji dan dianalisis, selanjutnya mengambil

${ }^{1}$ A.Dzajuli, Fiqh Jinayah: Upaya Menanggulangi Kejahatan dalm Islam, Cet I. Jakarta: Raja Grafindo Persada, 1996) hlm. 1

${ }^{2}$ Ibid, A.Dzajuli, hlm. V.

${ }^{3}$ Hasby Shiddiqi, Pidana Mati Dalam Syariat islam. Cet I. (Semarang: Pustaka Rizki Putera,1998) hlm. 17

${ }^{4}$ Satria Effendi M. zein, Kejahatan Terhadap harta dalam Perstektif Hukum Islam, dalam Muhammad Amin Suma, dkk, Pidana Islam di Indonesia, Peluang, Prospek, dan Tantangan (Jakarta: Pustaka Firdaus, 2001), hlm. 107

${ }^{5}$ Imam Muhammad bin Idris al-Syafi'i, al-Umm Buku 2, alih bahasa Imron Rosadi, dkk. (Jakarta : Pustaka Azam. 2009), Juz 7: hlm. 98 
pendapat yang lebih rajih serta sesuai dengan keadaan masyarakat Indonesia saat ini jika dikaitkan dengan asas persamaan dihadapan hukum yang dijamin pelaksanaannya oleh negara dalam undang-undang no 39 tahun 1999 tentang HAM (UU HAM).

Tulisan inimemaaparkan pendapat al-Syafi'i dan Abu Hanifah atas qishash, karena keduanya merupakan ulama besar dalam dunia Islam khususnya bidang fiqh dan menjadi panutan oleh semua orang dalam menjalankan aktifitasnya.

Adapun kajian ini meliputi latar belakang pemikiran kedua imam tersebut tentang sanksi hukuman mati terhadap pembunuhan non-muslim, istinbath hukum keduanya, serta hubungannya dengan asas persamaan dihadapan hukum sebagaimana yang berlaku di Indonesia.

\section{Metode Penelitian}

Penelitian menggunakan metode deskriptif dan komparatif, yakni penelitian dengan mengutamakan pengamatan terhadap gejala peristiwa dan membandingkan kondisi variabel pada satu tempat dengan tempat lain atau perbandingan antara masa sekarang dengan masa sebelumnya. ${ }^{6}$ Sehingga hubungannya dengan penelitian ini adalah mendeskripsikan pendapat al-Syafi'i dan Abu Hanifah tentang sanksi hukuman mati terhadap pembunuhan non-muslim yang kemudian dilakukan komparasi atau perbandingan atas pandangan tersebut. Berkaitan dengan penelitian ini, penulis akan menganalisis dari kedua pendapat tersebut dengan mengetahui bagaimana cara istinbath hukum dari keduanya sehingga dapat diketahui pendapat mana yang paling rajih dan relevan terhadap pendapat tersebut dengan perkembangan zaman khususnya dengan hak asasi manusia Indonesia.

Jenis data yang digunakan dalam penelitian ini adalah data kualitatif, yang datanya diperoleh dari kata-kata dan data tertulis. ${ }^{7}$ Data-data yang dimaksud berupa pendapatpendapat Imam madzhab, ulama, tokoh ilmuan, serta akademisi dari ahli hukum Islam yang tertuang pada beberapa literatur dan juga dalil-dalil hukum yang dijadikan landasan dari pemberian sanksi hukuman mati bagi pembunuh non-muslim.

Sumber data yang digunakan dalam penelitian ini adalah sumber data primer dan sekunder. Sumber data primer yang dimaksud adalah kitab pokok dari kedua imam madzhab tersebut yaitu Al-Uum karangan Imam al-Syafi'i dan al-Mabsut karangan Imam Syamsudin bin Abu Bakar Muhammad as-Syarkhasy yaitu ulama yang menganut madzhab Hanafiah. Adapun data sekundernya meliputi: kitab Fiqh Madzahibul Arba'ah karya Abdurrahman al-Jaziry, Fiqh Sunnah karya Sayyid Sabiq, Bidâyatul Mujatahid karya Ibnu Rusyd, dan Arkan Huqûqul Insan karya Subhi Mahmassani, serta buku-buku lain yang mendukung kajian ini.

\footnotetext{
${ }^{6}$ Tajul Arifin, Teknik Penulisan Skripsi, (Bandung : Gunung Djati Press, 2011) hlm. 38

${ }^{7}$ Cik Hasan Bisri, Penuntun Penyusunan Rencana Peelitian dan Penulisan Skripsi Bidang Ilmu Agama. Jakarta : Raja Grafindo Persada, 2003) hlm. 63
} 


\section{Hasil dan Pembahasan (Istinbath Hukum al-Syafi'i)}

Dalam kasus pembunuhan terhadap non muslim, al-Syafi'i berpendapat bahwa seorang muslim yang membunuh orang kafir (dzimmi) tidak dihukum mati (qishash), karena keduanya tidak ada kesamaan dalam hal keyakinan. Hal ini seperti yang dikatakannya dalam kitab al-Umm:

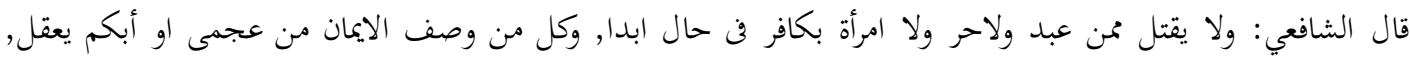

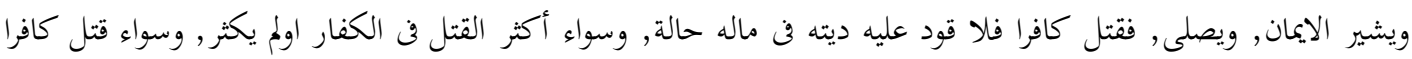

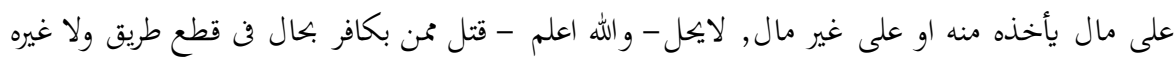

Al-Syafi'i berkata: "Dan tidaklah seorang mu'min dibunuh baik itu hamba atau orang merdeka dan tidak pula wanita, karena membunuh orang kafir dalam satu keadaaan selama-lamanya. Dan setiap yang mensifatkan iman dari orang 'ajam dan orang bisu yang berakal dan dapat berisyarat dengan iman dan dia mengerjakan shalat, lalu dia membunuh orang kafir, maka tidak ada qishash atasnya dan atasnya diyat atas hartanya pada seketika apakah dia memperbanyak pembunuhan di kalangan orang-orang kafir atau tidak. Dan sama dia membunuh orang kafir karena harta yang mana orang kafir mengambil dari padanya atau bukan karena harta. Tidak halal, walluhu a'lam, membunuh orang mu'min karena membunuh orang kafir dengan seketika pada perampokan dan tidak lainnya.. ${ }^{8}$

Al-Syafi'i berpijak pada al-Quran surat al-Baqarah ayat 178:

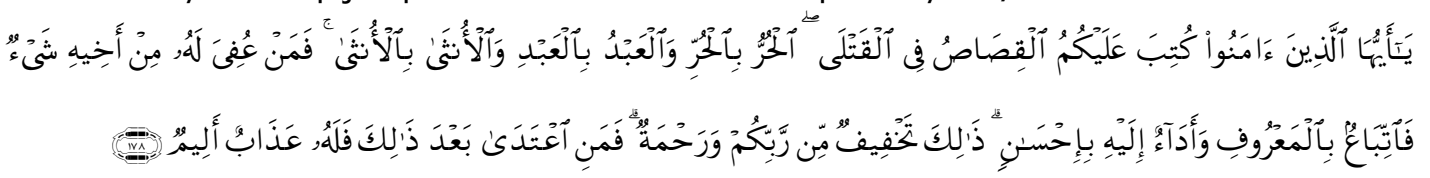

"Hai orang-orang yang beriman, diwajibkan atas kamu qishaash berkenaan dengan orang-orang yang dibunuh; orang merdeka dengan orang merdeka, hamba dengan hamba, dan wanita dengan wanita. Maka barangsiapa yang mendapat suatu pema'afan dari saudaranya, hendaklah (yang mema'afkan) mengikuti dengan cara yang baik, dan hendaklah (yang diberi ma'af) membayar (diat) kepada yang memberi ma'af dengan cara yang baik (pula). yang demikian itu adalah suatu keringanan dari Tuhan kamu dan suatu rahmat. barangsiapa yang melampaui batas sesudah itu, Maka baginya siksa yang sangat pedih."

Al-Syafi'i berpendapat bahwa qishash itu diwajibkan atas orang yang dewasa yang diwajibkan atas mereka yang dikithab (yang ditujukan) dengan kewajiban itu apabila mereka membunuh orang mukmin berdasarkan permulaan ayat di atas. Sesungguhnya dijadikan persaudaraan di antara orang-orang mu'min sebagaimana firman Allah SWT dalam surat al-Hujurat ayat 10 berikut ini:

${ }^{8}$ Imam Muhammad bin Idris al-Syafi'i, al-Umm Buku 2, alih bahasa Imron Rosadi, dkk. (Jakarta : Pustaka Azam. 2009), Juz 7: hlm. 98 


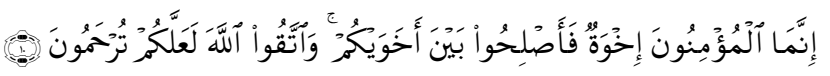

"Orang-orang beriman itu sesungguhnya bersaudara. Sebab itu, damaikanlah (perbaikilah hubungan) antara kedua saudaramu itu dan takutlah terhadap Allah, supaya kamu mendapat rahmat"

Di samping itu, al-Syafi'i berpegangan pada beberapa hadits diantaranya sebuah hadits yang diriwayatkan oleh Ali r.a:

$$
\begin{aligned}
& \text { حدثنا أحمد بن يونس حدثنا زهير حدثنا مطرف أن عامرا حدثهم عن أبي جحيفة قال قلت لعلي ح حدثنا صدقة بن }
\end{aligned}
$$

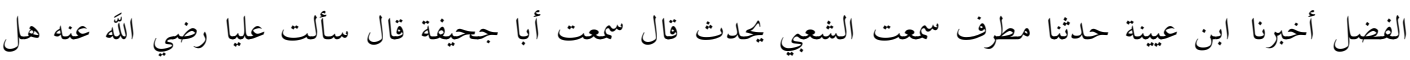

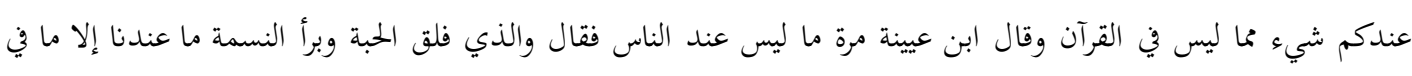

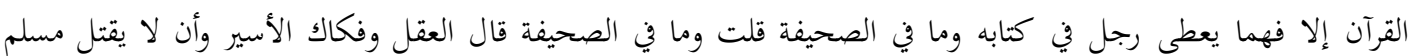

$$
\begin{aligned}
& \text { بكافر (رواه البخارى) }
\end{aligned}
$$

"Telah menceritakan kepada kami Ahmad bin Yunus telah menceritakan kepada kami Zuhair telah menceritakan kepada kami Mutharrif, bahwa Amir menceritakan kepada mereka, dari Abu Juhaifah mengatakan: Pernah aku berkata kepada Ali lewat jalur periwayatan lain-telah menceritakan kepada kami Shadaqoh bin Al Fadhl telah mengabarkan kepada kami Ibnu 'Uyainah telah menceritakan kepada kami Mutharrif Aku mendengar Asy Sya'bi menceritakan dengan mengatakan: aku mendengar Abu Juhaifah mengatakan: aku bertanya kepada Ali radliallahu 'anhu: 'Apakah kamu mempunyai sesuatu yang tidak terdapat di dalam alqur'an? sesekali Ibnu Uyainah mengatakan dengan redaksi: 'sesuatu yang tidak dimiliki manusia?' ia menjawab: 'Demi Dzat yang membelah biji-bijian dan mencipta manusia, kami tidak mempunyai selain yang terdapat dalam al Qur'an, kecuali pemahaman yang diberikan kepada seseorang terhadap kitab-Nya dan yang terdapat dalam shahifah.' Saya bertanya: 'apa yang terdapat dalam shahifah? ia menjawab: kewajiban membayar diyat, membebaskan tawanan dan tidak boleh seorang muslim dibunuh karena orang kafir." ${ }^{\prime 9}$

Hal ini senada dengan yang dikatakannya dalam kitab al-Umm sebagai berikut:

$$
\text { عليه وسلم يوم الفتح : لا يقتل مؤمن الله : وسمعت عددأ من أهل العلم بالمغازى وبلغنى عن عدد منهم : أنه كان في خطبة رسول الله صلى الله }
$$

Al-Syafi'i berkata : "Dan saya mendengar beberapa orang dari ahli Maghazy dan sampai kepadaku dari bilangan mereka itu bahwa pada khutbah Rasulullah SAW pada hari penaklukan kota Makkah 'Tidak dibunuh mukmin atas kafir'.."10.

Apabila seorang mukmin membunuh orang kafir, maka orang mu'min dijatuhi hukuman ta'zir dan ditahan tidak sampai setahun, tetapi dia ditahan untuk diuji dengannya dan itu adalah termasuk sebagian dari ta'zir. Padahal jika si pembunuh

\footnotetext{
${ }^{9}$ Shahih Bukhari hadits no 6404 .

${ }^{10} \mathrm{Al}-$ Imam Muhammad bin Idris al-Syafi'i.. al-Umm, Juz VII. (T.t: Daarul Wafa, T.th) . HIm. 98
} 
dijatuhi hukuman ta'zir akan menimbulkan masalah baru, bisa saja pelaku lolos dari jeratan hukum, karena ta'zir harus melewati proses peradilan. Jika saja dalam peradilan terdapat penyelewengan-penyelewengan kekuasaan oleh hakim atau terdapat mafia hukum yang dapat meloloskan si pelaku dari jerat hukum.

Jika seorang muslim membunuh seorang nasrani, kemudian orang muslim itu murtad, sedangkan ahli waris orang nasrani tersebut menuntut supaya pelaku pembunuhan dapat dikenai hukum qishash. Lalu mereka (ahli waris) berkata : "ini adalah kafir", maka dia tidak dibunuh, karena dia membunuh orang nasrani itu dalam keadaan mukmin, maka tidak ada qishash tetapi hanya dikenai hukuman ta'zir dan diyat pada hartanya. Maka jika ia bertaubat, diterima dari padanya, dan jika tidak maka dia dibunuh atas kemurtadannya. Demikian juga kalau seorang muslim memukul seorang nasrani, maka dia melukainya kemudian dia murtad dari Islam, kemudian orang nasrani itu meninggal dan yang membunuh itu murtad maka dia tidak diqihas dari padanya, karena kematian itu disebabkan pukulan itu, sedangkan pukulan itu terjadi dimana orang yang memukul itu dalam keadaan muslim.

Jika seorang muslim itu murtad dari Islam, lalu dia membunuh seorang dzimmi maka ahli waris dzimmi itu menuntut qishash sebelum yang membunuh itu kembali ke Islam atau dia kembali kepada Islam, maka adalah sama. Ada dua pendapat dari salah satu keduanya wajib atasnya qishash, dan ini adalah yang paling utama dari keduanya karena dia membunuh dan dia bukan orang Islam, dan pendapat yang kedua tidak ada qishash atasnya dari sudut bahwa dia tidak mengku atas agamanya dia kembali atau dia membunuh. ${ }^{11}$

Dalam masalah ini al-Syafi'i lebih menekankan kepada aspek persamaan keyakinan. Apabila yang melakukan pembunuhan itu seorang dzimmi terhadap dzimmi lainnya, maka qishash diterapkan. Namun jika yang melakukan pembunuhan itu seorang Muslim, maka ia tidak dikenakan qishash, akan tetapi hanya dipenjara sebagai sanksi atas perbuatannya.

Dalam menetapkan sanksi, Imam al-Syafi'i mengacu pada ayat al-Qur'an yang langsung diambil dari nash secara zhahir lafd الحر بالحر و العبد بالعبد و لأنثى بالأنثى ا. Pemahaman Imam al-Syafi'i terhadap nash tersebut sama dengan madzhab lainnya, bahwa yakni persamaan antara pelaku dan korban merupakan syarat yang harus dipenuhi dalam menerapkan qishash. ${ }^{12}$

Yang dimaksud sepadan di atas bukan berarti membedakan antara orang terpandang dengan orang rendahan, antara yang tampan dan yang jelek, antara yang kaya dengan yang miskin, antara yang tinggi dengan yang pendek, antara yang lemah dengan yang kuat, antara yang sehat dengan yang sakit, antara yang yang berbadan

${ }^{11}$ al-Imam al-Syafi'i, al-Umm (Kitab Induk), alih bahasa Ismail Yakub, Kuala Lumpur : Victory Agencie. 2000) hlm. 233

${ }^{12}$ Ibnu Hazm, al-Muhalla., (Beirut: Dar al-Fikr, t.t) VII : hlm. 352 
normal dengan yang cacat, antara yang kecil dengan besar, antara laki-laki dengan perempuan. namun kesamaan dari sisi keimanannya. Islam memandang adanya perbedaan antara Muslim dan kafir karena tidak adanya kesetaraan antara pembunuh dengan yang dibunuh dalam hal kesamaan keyakinan. ${ }^{13}$ Oleh karena itu dalam kasus pembunuhan dzimmi, sanksi qishash tidak dapat diterapkan, karena secara prinsip orang Muslim dan orang dzimmi berbeda dan tidak dapat disamakan sama sekali.

Al-Syafi'i menegaskan bahwa sanksi qishash tidak dapat diterapkan dalam kasus ini, karena secara zhahir nash tidak disebutkan berlaku bagi pembunuhan terhadap orang dzimmi. Adapun lafadz فمن عفي له من اخيه dalam ayat di atas dipamahi apabila pelaku diberi maaf oleh saudaranya, maka orang tersebut tidak dikenakan qishash namun diyat. Kata اخيه disini tidak menunjukan saudara seketurunan yang berkeyakinan sama tetapi bukan saudara dalam satu keturunan, dikarenakan al-Syafi'i beranggapan bahwa saudara senasab belum tentu mereka satu keyakinan. Maka yang memberikan maaf terhadap orang yang membunuh adalah orang yang berkeyakinan sama, tetapi tidak menutup kemungkinan saudara senasab adalah saudara satu keyakinan. Sehingga penerapan sanksi qishash bisa dihapus dengan adanya maaf dari saudara yang sama yaitu satu keyakinan. Abdurrahman al-Jaziry dalam kitabnya Fiqh Madzahibal-Arba'ah memperjelas pendapat al-Syafi'i sebagai berikut: ${ }^{14}$

$$
\begin{aligned}
& \text { يشترط عندهم في القاتل مكا فأته ومساوته للقتيل في الصفة بأن لم يفضله بإسلام او امان او حرية او اصلية او سيادة ويعتبر }
\end{aligned}
$$

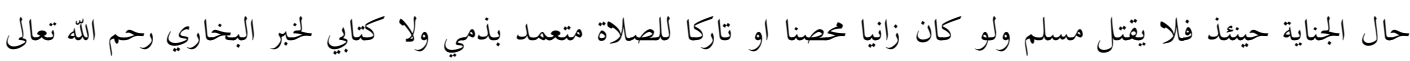

$$
\begin{aligned}
& \text { عن الرسول اللهصلى اللهعلليه وسلم لا يقتل مسلم بذمي. }
\end{aligned}
$$

"Disyaratkan adanya persamaan sifat antara si pembunuh dan yang dibunuh, sehingga tidak ada yang lebih utama baik itu karena Islam, iman, merdeka, asli, majikan, dan kedua dihitung peristiwa itu pada waktu kejadian atau saat itu juga. Maka tidak dibunuh seorang muslim oleh orang kafir dzimmi dan ahli kitab, sekalipun ia seorang zina muhson, meninggalkan solat dengan sengaja, sebagaimana hadits yang diriwayatkan oleh Bukhari semoga Allah SWT merahmatinya, dari Rasulullah SAW ia bersabda "tidaklah dibunuh seorang muslim oleh seorang dzimmi"."

\section{Istinbath Hukum Abu Hanifah}

Mayoritas ahli fiqh (Maliki, Syafi'i, Hambali) berpendapat bahwa muslim yang membunuh orang dzimmi tidak dihukum qishash. Mereka beralasan bahwa firman Allah dalam surat al-Baqarah ayat 178 mengandung pengertian Allah mewajibkan persamaan, yaitu sebanding antara pembunuh dan yang dibunuh seperti budak dengan budak,

\footnotetext{
${ }^{13}$ Sayyid Sabiq. Fiqh Sunnah Jilid IV, Vet III, alih bahasa Abdurrakhim dan Masrukhin (Jakarta : Cakrawala Publishing, 2012) hlm. 408

${ }^{14}$ Abdurrahman al-Jaziry, al-Fiqh 'ala Madzhab al-Arba'ah, Juz V, (Cairo: Maktabah Taufiqiyyah, 2012) hlm. 269
} 
wanita dengan wanita, dan orang merdeka dengan orang merdeka. Imam Abu Hanifah berpendapat lain, qishash diwajibkan atas seluruh manusia dalam hal pembunuhan, dan tidak melihat adanya perbedaan keyakinan antara pelaku dan korban, antara muslim dan dzimmi. Hal ini sesuai dengan yang tertulis dalam kitab al-Mabsuth sebagai berikut: ${ }^{15}$

$$
\begin{aligned}
& \text { أن وجوب القصاص يعتمد المساوة في الذمي وقد تحقق ذلك, والحكمة في شرع القصاص الحياة, وفي ذلك المعن الحر } \\
& \text { والمملوك سواء, وكذلك لو قتل المسسلم الذمي عمدا فعليه القصاص عنداندا. }
\end{aligned}
$$

"Bahwasanya kewajiban melaksanakan qishash itu bersandar akan persamaan dan tanggungan perlindungan, adapun hikmah dalam pensyariatan qishash adalah kehidupan, dengan demikian maka orang merdeka dengan budak yang dimiliki itu sama. Begitu juga seandainya seorang muslim membunuh seorang kafir dzimmi dengan sengaja maka wajib qishash, begitu menurut pendapat kami."

Pendapat Abu Hanifah tentang berlakunya qishash terhadap pembunuh yang dilakukan orang muslim terhadap dzimmi didasarkan pada firman Allah surat al-Baqarah ayat 178:

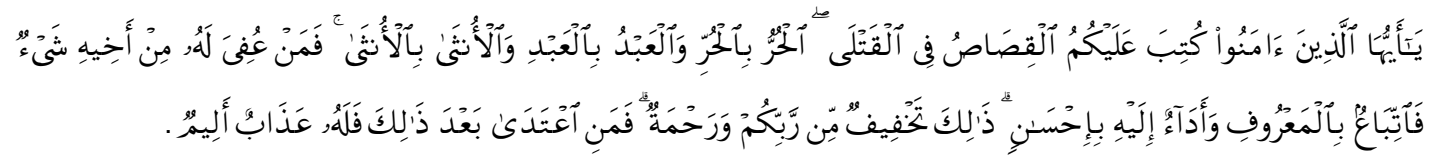

"Hai orang-orang yang beriman, diwajibkan atas kamu qishash berkenaan dengan orang-orang yang dibunuh; orang merdeka dengan orang merdeka, hamba dengan hamba, dan wanita dengan wanita. Maka barangsiapa yang mendapat suatu pema'afan dari saudaranya, hendaklah (yang mema'afkan) mengikuti dengan cara yang baik, dan hendaklah (yang diberi ma'af) membayar (diat) kepada yang memberi ma'af dengan cara yang baik (pula). yang demikian itu adalah suatu keringanan dari Tuhan kamu dan suatu rahmat. barangsiapa yang melampaui batas sesudah itu, Maka baginya siksa yang sangat pedih."

Ayat di atas mengandung pen gertian bahwa Allah mewajibkan hukum bunuh bagi setiap pembunuhan dengan tidak dibedakan apakah ia merdeka atau budak, muslim atau dzimmi. Awal ayat itu umum dan akhirnya khusus. Menurut Abu Hanifah, pengertian khusus pada akhir ayat tidak mengubah pengertian umum pada awal ayat, melainkan masing-masing dapat berlaku menurut hukumnya, baik yang umum atau yang khusus. Adapun makna dari lafadz surat al-Baqarah diatas yaitu الحر بالحر والعبد بالعبد ولأنثى بالأنثى maksudnya adalah untuk membatalkan kebiasaan yang dilakukan orang jahiliyah yang selalu menuntut ganti untuk dibunuh. Kalau seorang laki-laki merdeka yang terbunuh, gantinya dua orang laki-laki atau lebih dari pihak pembunuh. Apabila seorang budak

\footnotetext{
${ }^{15}$ Imam Syamsudin Abu Bakr Muhammad al-Syarkhasy, al-Mabsuth. (Beirut: Daar al-Fikri 2000): hlm.
} 117. 
yang terbunuh, mereka minta orang laki-laki merdeka yang akan dibunuh sebagai gantinya. Hal ini didukung oleh hadits Rasulullah SAW: ${ }^{16}$

حدثنا قتيبة بن سعيد حدثنا ابن أبي عدي عن ابن إِسحق هو محمّد ببعض هذا ح و حدثنا عبيد اللَّه بن عمر بن ميسرة حدثني هشيم عن يجيى بن سعيد جميعا عن عمرو بن شعيب عن أبيه عن جده قال قال رسول اللَّ صلّى اللّ عليه وسلم المسلمون تتكافأ دماؤهم يسعى بذمتهم أدناهم ويجير عليهم أقصاهم وهم يد على من سواهم يرد مشدهم على مضعفهم ومتسريهم على قاعدهم لا يقتل مؤمن بكافر ولا ذو عهد في عهده ولم يذكر ابن إسحق القود والتكافؤ (رواه ابوداؤد)

"Telah menceritakan kepada kami Qutaibah bin Sa'id, telah menceritakan kepada kami Ibnu Abu Adi dari Ibnu Ishaq Muhammad, dengan sebagian hadits ini. Dan telah diriwayatkan dari jalur yang lain: Telah menceritakan kepada kami 'Ubaidullah bin Umar bin Maisarah, telah menceritakan kepadaku Husyam dari Yahya bin Sa'id seluruhnya berasal dari 'Amr bin Syu'aib dari ayahnya, dari kakeknya, ia berkata; Rasulullah shallallahu 'alaihi wasallam bersabda: 'Orangorang muslim darah mereka sederajat, orang yang paling rendah diantara mereka berjalan dengan jaminan keamanan dari mereka, orang terjauh mereka memberikan perlindungan kepada mereka dan mereka adalah satu tangan atas orang selain mereka, orang kuat mereka membantu orang lemah mereka, dan orang yang berperang atas orang yang tidak berperang. Orang yang mukmin tidak dibunuh dibunuh lantaran orang kafir, dan tidak pula dibunuh orang yang memiliki perjanjian selama dalam perjanjiannya.' Sedangkan Ibnu Ishaq tidak menyebutkan balasan dan persamaan."

Argumen Abu Hanifah ini tertuang pula dalam kitab Fiqh Madzahib al-Arba'ah: ${ }^{17}$ يقتل المسلم بالذمي لأن الله تعالى قال: الحر بالحر والعبد بالعبد والأنثى بالأنثى فهو تخصيص بالذكر وهو لا ينافي ما عداه, كما في قوله ولأنثي بالأنثي فإنه لاينافي بالذكر بالأننثي, ولا العكس بالإجماع وفائدة التخصيص الرد على من اراد غير القاتل

"Orang Islam dibunuh oleh orang dzimmi, karena sesungguhnya Allah SWT berfirman 'orang merdeka dengan orang merdeka dan hamba sahaya dengan hamba sahaya dan perempuan dengan perempuan', itu mengkhususkan laki-laki dan ayat itu juga tidak menafikan yang selainnya sebagaimana firman Allah 'perempuan dengan perempuan', maka sesungguhnya ayat itu tidak menafikan laki-laki dibunuh oleh perempuan dan tidak pula sebaliknya, menurut kesepakatan ulama. Namun faedah menghkususkan itu adalah penolakan terhadap orang yang hendak membunuh orang yang selain si pembunuh."

Adapun hadits nabi SAW "Tidak dibunuh muslim karena membunuh kafir" itu tidak berlaku secara jelas dan total, hal ini disepakati karena si pembunuh itu apabila ia masuk Islam maka ia tetap harus dibunuh sebagai qishash, dalam hal ini dibunuh orang muslim oleh orang kafir. Kemudian yang dimaksud dengan kafir disini adalah kafir harbi, artinya

\footnotetext{
${ }^{16}$ Sunan Abu Dawud hadits No. 2371.

${ }^{17}$ Abdurrahman al-Jaziry, al-Fiqh 'ala Madzhab ... hlm. 270
} 
bagi orang yang tidak halal membunuhnya dari penduduk harbi seperti wanita dan anakanak, maka tidaklah dibunuh orang-orang mukmin oleh mereka dengan dalil "Tidak dibunuh seorang yang memiliki perjanjian selama dalam perjanjiannya" seperti hadits yang diriwayatkan oleh Abu Dawud di atas. ${ }^{18}$ Orang kafir dzimmi dan orang Islam mempunyai kesamaan dalam hal kehormatan yang mencukupkan untuk dilakukan qishash yaitu kehormatan darah, keduanya telah menjadi bagian dari penduduk darul (wilayah) Islam. Adapun yang membenarkan pernyataan itu adalah bahwa seorang muslim akan dipotong tangannya karena sebab mencuri harta seorang kafir dzimmi, ini menunjukan bahwa harta kafir dzimmi itu sama dan setara dengan harta orang muslim, maka ini juga menunjukan persamaan dan kesetaraan darahnya. ${ }^{19}$ Dalam sebagian riwayat lain dijelaskan bahwa seorang laki-laki muslim membunuh seorang dzimmi seperti yang tertuang dalam kitab al-Mabsuth sebagai berikut: ${ }^{20}$

$$
\begin{aligned}
& \text { وفي بعض الروايات أن رجلا مسلما قتل ذميافتضى رسول الله صل الله عليه وسلم بالقصاص وقال: "انا احق من وفي بذمته" }
\end{aligned}
$$

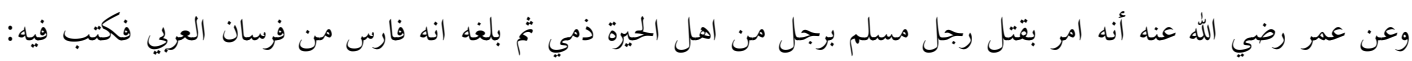

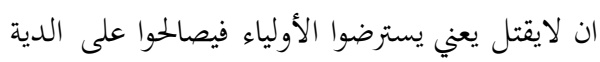

"Bahwasanya seorang laki-laki muslim membunuh seorang dzimmi, lalu Rasulullah memutuskan untuk mengqishashnya dan bersabda 'aku adalah yang paling berhak terhadap orang yang menempati tanggungjawabnya'. Dari Umar r.a bahwasanya ia memerintahkan kepada seorang laki-laki dzimmi, penduduk di suatu wilayah agar membunuh laki-laki muslim, lalu kemudian sampailah kepada Umar bahwa laki-laki tersebut seorang Persia Arab, maka ia memutuskan bahwa laki-laki muslim itu tidak dibunuh dalam arti meminta ridho atau kerelaaan para walinya lalu menyelesaikan atau memberekan dan mendamaikannya dengan membayar diyat/denda."

Berdasarkan penjelasan ini dapat diketahui bahwa Rasulullah memberikan hukum qishash dalam pembunuhan yang disengaja, tidak membedakan antara orang yang dibunuh dengan lainnya. Berarti maksud dari hadits ini berlakunya hukum qishash diantara orang muslim dan kafir (dzimmi) selama pembunuhan dilakukan dengan sengaja. Pendapat Abu Hanifah tentang diwajibkan qishash bagi pembunuhan terhadap dzimmi juga berdasarkan firman Allah dalam surat al-Maidah ayat 45 yang berbunyi:

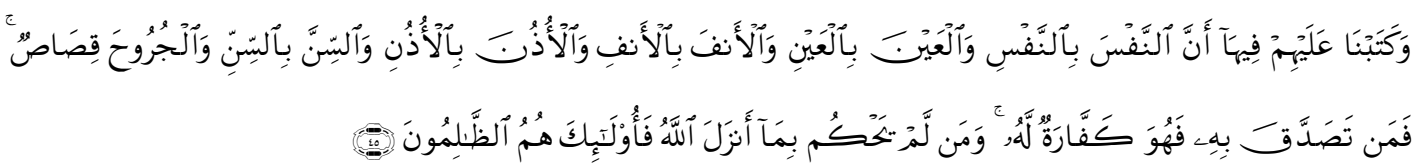

"Dan Kami telah tetapkan terhadap mereka di dalamnya (At Taurat) bahwasanya jiwa (dibalas) dengan jiwa, mata dengan mata, hidung dengan hidung, telinga dengan telinga, gigi dengan gigi, dan luka luka (pun) ada kisasnya. barangsiapa

\footnotetext{
${ }^{18}$ Imam Syamsudin Abu Bakr Muhammad al-Syarkhasy, al-Mabsuth., hlm. 120

${ }^{19} \mathrm{lbid}$. A bdurrahman al-Jaziry, hlm. 270

${ }^{20}$ Imam Syamsudin Abu Bakr Muhammad al-Syarkhasy, hlm. 118
} 
yang melepaskan (hak kisas) nya, Maka melepaskan hak itu (menjadi) penebus dosa baginya. barangsiapa tidak memutuskan perkara menurut apa yang diturunkan Allah, Maka mereka itu adalah orang-orang yang zalim."

Ayat tersebut menegaskan secara umum wajibnya qishash bagi orang-orang yang terbunuh dan (شرع من قبلنا) sepanjang tidak dinasakh berlaku juga untuk kita. Dengan demikian bahwa jelaslah menurut Abu Hanifah, apabila seorang muslim membunuh seorang dzimmi maka wajib qishash.

\section{Perbandingan Pendapat al-Syafi'i dan Abu Hanifah Tentang Sanksi Hukuman Mati Terhadap Pembunuh Non Muslim}

Pembunuhan menurut ulama fiqh adalah perbuatan seseorang terhadap orang lain yang mengakibatkan hilangnya nyawa, baik perbuatan tersebut dilakukan dengan sengaja maupun tidak disengaja. ${ }^{21}$ Membunuh dengan alasan yang dibenarkan oleh hukum syara' diperbolehkan dan tidak menjadi masalah. Terkait dengan pembunuhan yang dilakukan oleh muslim terhadap non-muslim, sebagaimana telah dijelaskan sebelumnya terdapat perbedaan pendapat antara al-Syafi'i dan Abu Hanifah mengenai sanksi yang diterapkan dalam situasi tersebut. Berikut ini uraian singkat mengenai letak kelebihan dan kekurangan antara al-Syafi'i dan Abu Hanifah, sehingga kita dapat menilai secara objektif suatu pendapat dari kedua tokoh tersebut. Adapun kelebihan dan kekurangan dari kedua tokoh tersebut dapat penulis jelaskan sebagai berikut:

1. Pendapat al-Syafi'i dalam memahami surat al-Baqarah ayat 178 lebih mengedepankan dhahir nash/dhahir lafd tanpa melihat illat yang terkandung dalam teks tersebut. Sedangkan Abu Hanifah yang pemikirannya cenderung mengedepankan akal/rasio memahami teks tidak hanya secara dzahir, akan tetapi melihat maksudmaksud yang terkandung di dalam teks.

2. Pendapat al-Syafi'i yang tidak mewajibkan qishash bagi pelaku tindak pidana pembunuhan non-muslim dipandang tidak adil dan membedakan kedudukan manusia di hadapan hukum, sedangkan pendapat Abu Hanifah yang mewajibkan qishash bagi pelaku tindak pidana pembunuhan terhadap non-muslim dipandang lebih adil dan tidak membedakan manusia di hadapan hukum.

3. Pemikiran al-Syafi'i yang menyeimbangkan antara ahlu ra'yu dan ahlu hadits akan menumbuhkan rasa kehati-hatian dalam berijtihad dan mengeluarkan sebuah hukum, sedangkan Abu Hanifah yang mengedepankan akal (rasio) akan memunculkan kebebasan berfikir tanpa kontrol dan meninggikan akal daripada wahyu.

4. Pendapat al-Syafi'i yang mengharuskan adanya persamaan agama atau keyakinan antara pembunuh dan yang dibunuh atau antara muslim dengan kafir adalah

\footnotetext{
${ }^{21}$ Ahmad Wardi Muslih,Hukum Pidana Islam, Jakarta : Sinar Grafika, 2005) hlm. 137
} 
semata-mata untuk melindungi harkat martabat Islam yang lebih tinggi derajatnya dibanding orang agama lain (kafir). Sedangkan Abu Hanifah lebih mengedepankan asas persamaan dimuka hukum, hal ini pun sejalan dengan perkembangan hukum pidana modern dan Islam sebagai rahmatan lil'alamin.

Jadi, masing-masing pendapat tersebut mempunyai nilai positif dan negatif dalam penerapan sanksi pembunuhan terhadap non-muslim. Menurut pendapat penulis bahwa al-Syafi'i berpendapat seperti itu didasarkan pada konteks saat itu, jika pendapat ia tidak diterapkan akan menimbulkan bahaya bagi kehidupan masyarakat saat itu. Sehingga perlu menerapkan hukum-hukum yang tersurat dalam al-Qur'an dan Sunnah secara ketat. Namun paradigma semacam ini kalau ditarik dalam konteks kehidupan sekarang, maka muncul pertanyaan akankah kita akan mempertahankan dan bersikukuh dengan pendapat al-Syafi'i tersebut? Hal ini didasarkan kepada persoalan bahwa seting sosial sudah berbeda dan sementara kebutuhan ijtihad akan selalu bergulir selagi manusia beraktivitas (interaksi). Persoalan hukum terus bermunculan sementara nash sangat terbatas. Dalam konteks semacam inilah manusia dituntut untuk menggali syariat Allah dengan mempertimbangkan aspek maslahah.

Sebagaimana telah dikemukakan di atas, bahwa al-Syafi'i tidak memberikan hukuman qishash ataupun diat bagi pelaku tindak pidana pembunuhan terhadap nonmuslim, baik dilakukan sengaja maupun tidak sengaja, melainkan hanya diberikan hukuman penjara. Jadi setiap pembunuhan yang dilakukan oleh muslim terhapap nonmuslim tidak wajib di qishash. Al-Syafi'i menolak kelompok ulama yang mengatakan bahwa wajibnya qishash bagi pelaku tindak pidana pembunuhan non-muslim dan menolak dasar-dasar yang dijadikan pegangan itu.

Menurut penulis yang menjadikan al-Syafi'i dengan pendapatnya bahwa tidak wajib qishash bagi pelaku tindak pidana pembunuhan terhadap non-muslim adalah menggunakan dalil al-Quran surat al-Baqarah ayat 178 pada firman Allah: "Diwajibkan kepada kamu qishash". Di situ disyaratkan adanya persamaan dalam pembalasan (karena arti kata qishash ialah pembalasan yang sama). Kemudian al-Syafi'i mempertalikan ayat dengan awalnya dan penjelasan ayat itu dititikberatkan kepada sambungannya, sebagaimana firman Allah: "Diwajibkan atas kamu qishash dalam pembunuhan, orang merdeka untuk orang merdeka, hamba sahaya untuk hamba sahaya dan wanita untuk wanita". Kalimat dalam ayat tersebut belum dianggap sempurna kalau belum sampai kata "wanita untuk wanita". Itulah yang penulis maksud, bahwa dalam mempertahankan pendapatnya tersebut, al-Syafi'i melihat dhahir lafdz/dhahir nash pada ayat tersebut tanpa melihat dari sisi lain. Al-Syafi'i berpendapat bahwa dhahir ayat itu menunjukan harus adanya persamaan antara pembunuh yang dibunuh, termasuk persamaan dalam hal keimanan. 


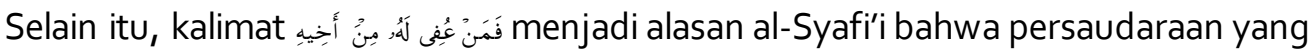
dimaksud dalam ayat tersebut adalah saudara se-iman, bukan saudara se-nasab. Sebagaimana firman Allah SWT dalam surat al-Hujuat ayat 10: "Sesungguhnya orang mukmin itu bersaudara". Dengan demikian, maka terputuslah hubungan diantara orangorang mukmin dan orang kafir, karena begitulah menurut dhahir ayat tersebut. Mukmin dengan kafir jelas tidak bisa dipersamakan dalam hal apapun. ${ }^{22}$ Pendapat al-Syafi'i yang mengatakan bahwa pembunuhan yang dilakukan oleh muslim terhadap non-muslim tidak diqishash didasarkan kepada hadits Nabi yang menjelaskan tentang muslim tidak bunuh karena membunuh non-muslim, sabda Nabi yang berbunyi :

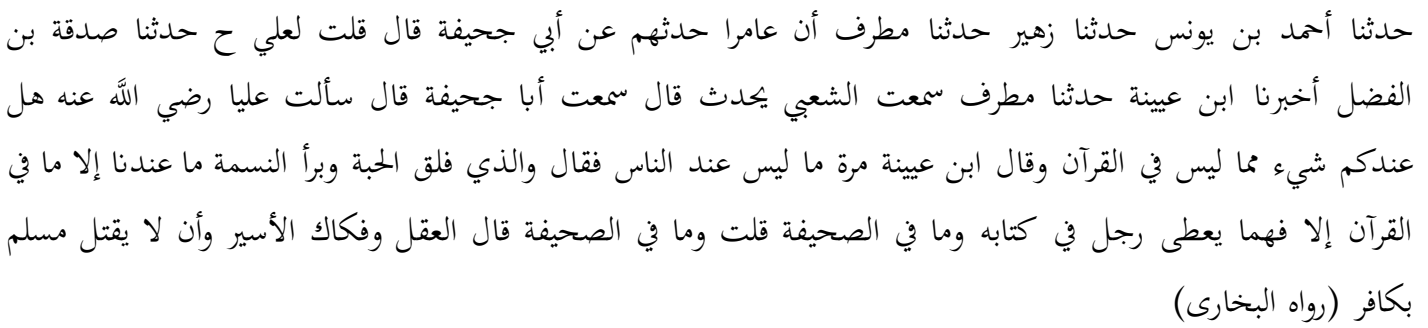

"Telah menceritakan kepada kami Ahmad bin Yunus telah menceritakan kepada kami Zuhair telah menceritakan kepada kami Mutharrif, bahwa Amir menceritakan kepada mereka, dari Abu Juhaifah mengatakan; Pernah aku berkata kepada Ali lewat jalur periwayatan lain-telah menceritakan kepada kami Shadaqoh bin Al Fadhl telah mengabarkan kepada kami Ibnu 'Uyainah telah menceritakan kepada kami Mutharrif Aku mendengar Asy Sya'bi menceritakan dengan mengatakan; aku mendengar Abu Juhaifah mengatakan; aku bertanya kepada Ali radliallahu 'anhu; 'Apakah kamu mempunyai sesuatu yang tidak terdapat didalam alqur'an? sesekali Ibnu Uyainah mengatakan dengan redaksi; 'sesuatu yang tidak dimiliki manusia?' ' ia menjawab; 'Demi Dzat yang membelah biji-bijian dan mencipta manusia, kami tidak mempunyai selain yang terdapat dalam al Qur'an, kecuali pemahaman yang diberikan kepada seseorang terhadap kitab-Nya dan yang terdapat dalam shahifah.' Saya bertanya; 'apa yang terdapat dalam shahifah? ia menjawab: kewajiban membayar diyat, membebaskan tawanan dan tidak boleh seorang muslim dibunuh karena orang kafir. ${ }^{123}$

Menurut al-Syafi'i bahwa hadits tersebut menunjukkan secara jelas bahwa pembunuhan yang dilakukan oleh muslim terhadap non-muslim adalah tidak di-qishash karena orang dzimmi (non-muslim yang meminta perlindungan kepada muslim) itu tetap dihukumi kafir. Hadits tersebut bersifat umum dan tidak berlaku khusus pada kafir harbi melainkan juga berlaku bagi kafir dzimmi. Bertolak dari pendapat al-Syafi'i tersebut, maka dapat diambil suatu kesimpulan bahwa yang menjadikannya berpendapat bahwa tidak di-qishash bagi pelaku tindak pidana pembunuhan terhadap non-muslim

${ }^{22}$ Muhammad Bin Idris Asy-Syafi'I, Imam Abi Abdillah, Al-Umm, (Beirut-Libanon : Dar Al-Kitab, Juz7, T.th) hlm. 97

${ }^{23}$ Shahih Bukhari hadits no 6404 
adalah karena al-Syafi'i memahami surat al-Baqarah ayat 178 tersebut di atas secara tekstual/dhahir nash dan berlaku umum tanpa adanya pengkhususan. Padahal surat alBaqarah ayat 178 di atas dimaksudkan untuk menghilangkan tindak kezaliman yang lazim berlaku dalam masyarakat jahiliyah, di mana mereka membalas pembunuhan hamba dengan orang merdeka, wanita dengan laki-laki secara melampaui batas dan zalim, maka Allah membatalkan tindakan tersebut dan mengukuhkan bentuk hukuman qisas bagi pembunuh.

Al-Syafi'i menyanggah dari kelompok ulama yang berpendapat bahwa muslim yang membunuh non-muslim itu berlaku hukuman qishash yang didasarkan kepada hadits nabi:

$$
\begin{aligned}
& \text { حدثنا قتيبة بن سعيد حدثنا ابن أبي عدي عن ابن إسحق هو محمّد ببعض هذا ح و حدثنا عبيد اللَّ بن عمر بن ميسرة }
\end{aligned}
$$

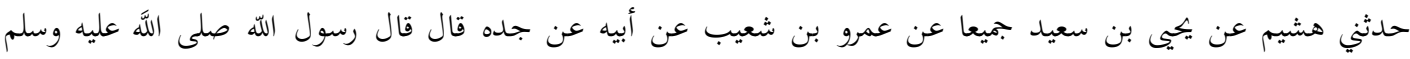

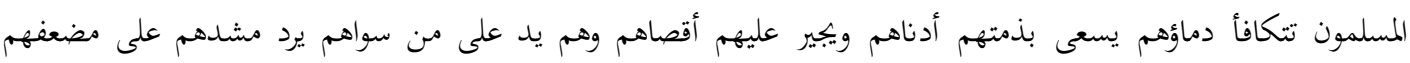

$$
\begin{aligned}
& \text { ومتسريهم على قاعدهم لا يقتل مؤمن بكافر ولا ذو عهد في عهله ولم يذكر ابن إسحق القود والتكافؤ (رواه ابؤداود) }
\end{aligned}
$$

"Telah menceritakan kepada kami Qutaibah bin Sa'id, telah menceritakan kepada kami Ibnu Abu Adi dari Ibnu Ishaq Muhammad, dengan sebagian hadits ini. Dan telah diriwayatkan dari jalur yang lain: Telah menceritakan kepada kami 'Ubaidullah bin Umar bin Maisarah, telah menceritakan kepadaku Husyam dari Yahya bin Sa'id seluruhnya berasal dari 'Amr bin Syu'aib dari ayahnya, dari kakeknya, ia berkata; Rasulullah shallallahu 'alaihi wasallam bersabda: "Orangorang muslim darah mereka sederajat, orang yang paling rendah diantara mereka berjalan dengan jaminan keamanan dari mereka, orang terjauh mereka memberikan perlindungan kepada mereka dan mereka adalah satu tangan atas orang selain mereka, orang kuat mereka membantu orang lemah mereka, dan orang yang berperang atas orang yang tidak berperang. Orang yang mukmin tidak dibunuh dibunuh lantaran orang kafir, dan tidak pula dibunuh orang yang memiliki perjanjian selama dalam perjanjiannya." Sedangkan Ibnu Ishaq tidak menyebutkan balasan dan persamaan. ${ }^{124}$

Hadits ini menunjukkan bahwa orang mukmin tidak diqishash karena membunuh orang kafir harbi, yang dimaksud dari lafadz ذُو عَهْدِ adalah kafir dzimmi dan lafadz tersebut

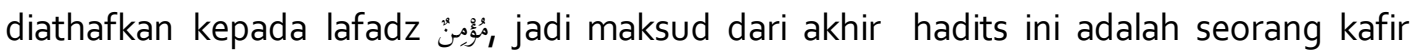
dzimmi juga tidak mendapat hukuman qishash karena membunuh kafir harbi, maka jelas yang dimaksud lafadz kafir dalam hadits ini adalah kafir harbi. Oleh karena itu dalam hadits ini tidak ada sama sekali petunjuk yang menjelaskan diqisasnya orang islam karena membunuh kafir zimmi. ${ }^{25}$

${ }^{24}$ Abu Daud, Sulaiman bin Asy'asy al-Sijitani, Sunan Abi Daud, (Dar-Hadits, Cairo, 1988 M), Hadits No. 2371 hlm. 256

${ }^{25}$ Abu Bakar bin Mas'ud al-Kasani, Badi'u ash-Shana'I, Juz 10, (Beirut: Daar al-Kutub al-Ilmiyah, t.t) 
Sedangkan Abu hanifah berpendapat bahwa qishash diwajibkan atas manusia dalam hal pembunuhan, dan tidak ada kaitannya antara keimanan dan kekafiran terbunuh. Hal ini sesuai dengan yang tertulis dalam kitab al-Mabsuth :

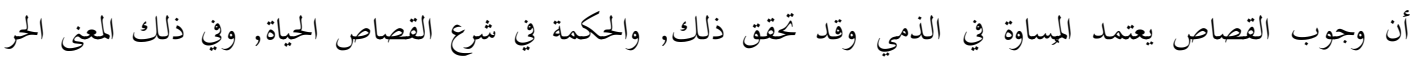

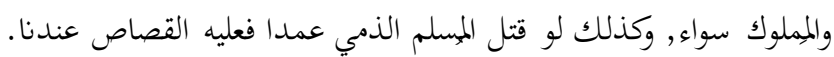

"Bahwasanya kewajiban melaksanakan qishash itu bersandar akan persamaan dan tanggungan perlindungan, adapun hikmah dalam pensyariatan qishash adalah kehidupan, dengan demikian maka orang merdeka dengan budak yang dimiliki itu sama. Begitu juga seandainya seorang muslim membunuh seorang kafir dzimmi dengan sengaja maka wajib qishash, begitu menurut pendapat kami. ${ }^{126}$

Pendapat Abu Hanifah tentang berlakunya hukuman qishash bagi pembunuh non muslim berdasarkan al-Quran surat al-Baqarah ayat 178 :"Diwajibkan kepada kamu qishash". Diriwayatkan dari Qatadah bahwa "...sebab turunnya ayat ini adalah, bahwa orang-orang jahiliyah biasa melakukan kedzaliman dan memperturutkan kehendak setan, yaitu apabila suatu kabilah memiliki kekuatan kemudian hamba mereka membunuh hamba dari kabilah lain maka mereka berkata: kami tidak akan membalas melainkan mesti membuhuh orang merdeka karena rasa keagungan dan keutamaan mereka atas yang lain dan apabila ada seorang perempuan membunuh seorang perempuan dari kabilah lain merekapun berkata kami tidak akan membalas membunuh melainkan seorang lelaki..." kemudian turunlah ayat "Orang merdeka dengan orang merdeka hamba dengan hamba dan wanita dengan wanita". ${ }^{27}$

Dalam keterangan ayat di atas mengandung pengertian bahwa Allah mewajibkan hukum qishash bagi setiap pembunuhan dengan tidak membedakan apakah ia merdeka atau budak, muslim atau dzimmi. Karena awal ayat itu umum dan akhirnya khusus. Pengertian khusus pada akhir ayat tidak mengubah pengertian umum pada awal ayat, melainkan masing-masing dapat berlaku menurut hukumnya, baik yang umum atau yang khusus. Menurut analisis penulis, Abu Hanifah berpendapat bahwa wajib qishash bagi pelaku tindak pidana pembunuhan non-muslim dikarenakan beliau memisahkan awal ayat dengan sambungannya, yakni awal ayat bermaksud untuk melaksanakan hukuman qishash dalam tindak pidana pembunuhan, sedangkan ayat kelanjutannya hanya untuk membatalkan tradisi yang ada pada zaman jahiliyah yang selalu ingin membalas lebih apabila dari pihak mereka terbunuh.

Argumen Abu Hanifah ini, seperti tertuang dalam kitab Fiqh Madzâhib al-Arba'ah:

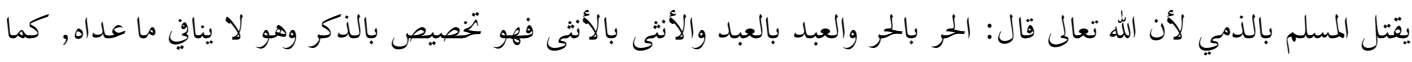

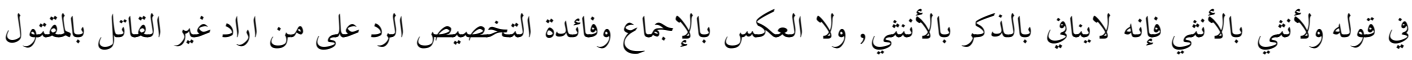

\footnotetext{
${ }^{26}$ Muhammad ibn Ahmad as-Sarakhsî, al-Mabsûth, jilid II (Beirut: Dâr al-Ma'rifah, 2000) hlm. 117

${ }^{27}$ Ali ash-Shabuni, Tafsir Ayat Ahkam, alih bahasa Mu'ammal Hamidi dkk. (Jakarta: PT Bina Ilmu, 1983)
} hlm. 123 
Orang Islam dibunuh oleh orang dzimmi, karena sesungguhnya Allah SWT berfirman "orang merdeka dengan orang merdeka dan hamba sahaya dengan hamba sahaya dan perempuan dengan perempuan", itu mengkhususkan laki-laki dan ayat itu juga tidak menafikan yang selainnya sebagaimana firman Allah "perempuan dengan perempuan", maka sesungguhnya ayat itu tidak menafikan laki-laki dibunuh oleh perempuan dan tidak pula sebaliknya, menurut kesepakatan ulama. Namun faedah menghkususkan itu adalah penolakan terhadap orang yang hendak membunuh orang yang selain si pembunuh. ${ }^{28}$ Sama halnya dengan al-Syafi'i bahwa Abu Hanifah menyandarkan pendapatnya pada hadits Nabi Muhammad SAW yang diriwayatkan oleh Abu Dawud dalam kumpulan hadits no 2371 tersebut di atas.

Dari penjelasan di atas dapat diketahui bahwa Abu Hanifah lebih memilih ditetapkannya qishash dalam kasus tersebut karena menurut beliau keadilanlah yang harus ditetapkan. Menurut penulis pendapat beliau seperti ini karena melihat banyak nash yang didalamnya dapat diambil kesimpulan bahwa agama Islam ini sangat menjunjung tinggi nilai-nilai kemanusiaan yang dalam hal ini kaitannya dengan berlaku adil, karena dengan demikian misi agama ini yakni membawa rahmat bagi seluruh alam akan terealisasikan dimana di dalamnya termuat nilai-nilai kemanusiaan yang tidak dipandang dari segi keimanannya, tapi dipandang dari kedudukannya sebagai makhluk Allah di muka bumi ini. Di antara nash-nash tersebut adalah sebagai berikut:

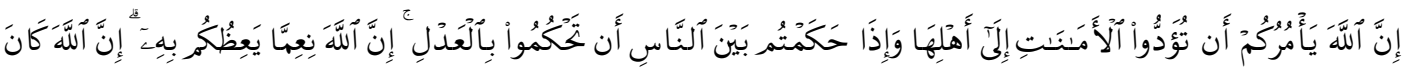
(a)

"Sesungguhnya Allah menyuruh kamu menyampaikan amanat kepada yang berhak menerimanya, dan (menyuruh kamu) apabila menetapkan hukum di antara manusia supaya kamu menetapkan dengan adil. Sesungguhnya Allah memberi pengajaran yang sebaik-baiknya kepadamu. Sesungguhnya Allah adalah Maha mendengar lagi Maha Melihat."

Berkaitan dengan hak asasi manusia di Indonesia, secara jelas dituliskan dalam undang-undang no 39 tahun 1999 tentang HAM khususnya pada pasal 3 ayat (1) yang berbunyi:

"Setiap orang dilahirkan bebas dengan harkat dan martabat manusia yang sama dan sederajat serta dikaruniai akal dan hati nurani untuk hidup bermasyarakat, berbangsa, dan berbegara dalam semangat persaudaraan".

Serta ayat (2) pasal yang sama menyebutkan bahwa:

"Setiap orang berhak atas pengakuan, jaminan, perlindungan dan pengakuan hukum yang adil serta mendapat kepastian hukum dan perlakuan yang sama di depan hukum".

Serta pada ayat (3)

\footnotetext{
${ }^{28}$ Abdurrahman al-Jaziry, al-Fiqh 'ala Madzhab ... hlm. 270
} 
"Setiap orang berhak atas perlindungan hak asasi manusia dan kebebasan dasar menusia, tanpa diskriminasi".

Hal senada pun tertuang pada pasal 4 yang berbunyi:

"Hak untuk hidup, hak untuk tidak disiksa, hak kebebasan pribadi, pikiran dan hati nurani, hak beragama, hak untuk tidak diperbudak, hak untuk diakui sebagai pribadi dan persamaan di depan hukum, dan hak untuk tidak di tuntut atas dasar hukum yang berlaku surut adalah hak asasi manusia yang tidak dapat dikurangi dalam keadaan apapun dan oleh siapapun".

Persaudaraan kemanusiaan yang bertentangan dengan diskriminasi rasia, fanatisme keagamaan atau diskriminasi lain di antara sesama manusia menghendaki adanya persamaan yang sempurna diantara manusia dalam pandangan syariat Islam. Oleh karena itu prinsip persamaan termasuk prinsip umum yang aksiomatik dan jelas dalam Islam. Islam menerapkan prinsip persamaan ini dalam masalah-masalah ibadah maupun hukum muamalah.

Dalam soal ibadah, orang mukmin wajib melaksanakan semua kewajiban agama berdasarkan asas yang satu dengan tanpa ada perbedaan antara satu dengan yang lain, baik warga negara asli maupun orang asing, laki-laki maupun perempuan.

Persamaan secara hukum dan undang-undang ialah persamaan seluruh manusia dihadapan undang-undang tanpa melihat adanya perbedaan di antara mereka dari sisi etnis, warna kulit, agama, bangsa, keturunan, dan tingkat ekonomi. Tidak dibedakan antara yang putih dengan yang hitam juga tidak dibedakan antara Nasrani atau Muslim atau lainnya, dan tidak pula antara kaya dengan yang miskin, antara cendikiawan dengan yang bodoh dan antara yang mulia dengan yang lemah. ${ }^{29}$ Dalam Islam kedudukan dan martabat seseorang tidak didasarkan pada status sosialnya, melainkan oleh derajat ketakwaannya. Adapun yang dimaksud dengan persamaan di depan hukum adalah khusus kesamaan dalam hal tindak pidana yang dilakukan oleh seseorang dan dijatuhi berdasarkan persamaan kemanusiaan seperti yang tercantum pada konsep kemanusiaan dalam Islam.

Melihat perbedaan yang muncul antara pendapat al-Syafi'i dan Abu hanifah tentang pemidanaan pelaku tindak pidana pembunuhan non muslim, penulis lebih cenderung terhadap pendapat Abu hanifah yang memberikan hukuman qishash bagi pelaku pembunuhan non-muslim tanpa membedakan unsur keimanan seseorang, karena inti dari suatu hukuman adalah memberikan suatu keadilan dan ketenteraman bagi masyarakat. Sehingga dengan adanya keadilan dan ketenteraman maka manusia tidak akan semena-mena melakukan pembunuhan atas dasar hawa nafsunya serta perasaan bahwa dirinya lebih dominan, berkuasa, kaya, dan sebagainya.

${ }^{29}$ Subhi Mahmassani, Konsep Dasar Hak-Hak Asasi Manusia, Suatu Perbandingan Dalam Syari'at Islam dan Perundang-Undangan, (Jakarta : PT. Tinta Mas Indonesia, 1993) hlm. 212 


\section{Simpulan}

Latar belakang pemikiran al-Syafi'i dan Abu Hanifah tentang sanksi hukuman mati terhadap pembunuh non muslim sangat dipengaruhi oleh latar belakang kehidupan, kondisi sosial masyarakat, pendidikan dan metode ijtihad yang berbeda antara al-Syafi'i dan Abu Hanifah.

Adapun istinbat hukum al-Syafi'i dan Abu Hanifah, dalam masalah ini adalah berdasarkan atas ayat al-Qur'an surat al-Baqarah ayat 178. Dalam ayat tersebut al-Syafi'i mengambil dzâhir nash yaitu harus ada persamaan keyakinan antara pembunuh dan yang dibunuh, sedangkan Abu hanifah menafsirkan ayat tersebut bukan adanya persamaan keyakinan antara pembunuh dan yang dibunuh melainkan persamaan hak dimuka hukum dan persamaan derajat manusia sebagai makhluk Allah SWT.

Pendapat al-Syafi'i dan Abu Hanifah mempunyai kekurangan dan kelebihan masing-masing jika dikaitkan dengan hak asasi manusia di Indonesia. Namun penulis lebih sepakat kepada pendapat Abu Hanifah karena pendapatnya itulah yang paling sesuai dengan hak asasi di Indonesia.

\section{Daftar Pustaka}

Al-Jaziry, Abdurrahman, 2012. al-Figh 'ala Madzhab al-Arba'ah, Juz V, Cairo: Maktabah Taufiqiyyah.

Al-Kasani, Abu Bakar bin Mas'ud, T.th Badi'u ash-Shana'l, Juz 10, Beirut: Daar al-Kutub al-Ilmiyah.

Al-Sijitani. Abu Daud, Sulaiman bin Asy'asy, 1988. Sunan Abi Daud, Cairo : Dar-Hadits, Hadits No. 2371

Arifin, Tajul. 2011. Teknik Penulisan Skripsi, Bandung : Gunung Djati Press

Bisri, Cik Hasan, 2003. Penuntun Penyusunan Rencana Peelitian dan Penulisan Skripsi Bidang Ilmu Agama. Jakarta : Raja Grafindo Persada,

Dzajuli, A., 1996. Figh Jinayah: Upaya Menanggulangi Kejahatan dalm Islam, Cet I. Jakarta: Raja Grafindo Persada,

Hazm, Ibnu, T, th. al-Muhalla., Beirut: Dar al-Fikr. Juz VII

Mahmassani, Subhi. 1993. Konsep Dasar Hak-Hak Asasi Manusia, Suatu Perbandingan Dalam Syari'at Islam dan Perundang-Undangan, Jakarta : PT. Tinta Mas Indonesia Muslih, Ahmad Wardi, 2005.Hukum Pidana Islam, Jakarta : Sinar Grafika,

Sabiq, Sayyid. 2012. Fiqh Sunnah Jilid IV, Vet III, alih bahasa Abdurrakhim dan Masrukhin (Jakarta : Cakrawala Publishing

Sarakhsî, Muhammad ibn Ahmad as-, 2000. al-Mabsûth, jilid II. Beirut: Dâr al-Ma'rifah, 2000

Shabuni, Ali ash. 1983. Tafsir Ayat Ahkam, alih bahasa Mu'ammal Hamididkk. Jakarta: PT Bina llmu.

Shahih Bukhari hadits no 6404

Shahih Bukhari hadits no 6404 .

Shiddiqi, Hasby. 1998. Pidana Mati Dalam Syariat islam. Cet I. Semarang: Pustaka Rizki Putera, 1998 
Sunan Abu Dawud hadits No. 2371.

Syafi'I, al-Imam al-, 2000.al-Umm (Kitab Induk), alih bahasa Ismail Yakub, Kuala Lumpur : Victory Agencie.

Syafi'l, al-Imam Muhammad bin Idris al-. t.th. al-Umm, Juz VII. t.t : Daarul Wafa,

Syafi'I, Imam Muhammad bin Idris al-, 2009. al-Umm Buku 2, alih bahasa Imron Rosadi, dkk. Jakarta : Pustaka Azam. Juz 7

Syafi'l, Muhammad Bin Idris Asy-, T.th Imam Abi Abdillah, Al-Umm, Beirut-Libanon : Dar Al-Kitab, Juz 7

Syarkhasy, Imam Syamsudin Abu Bakr Muhammad al-, 2000. al-Mabsuth. Beirut: Daar alFikri.

Zein, Satria Effendi M., 2001. Kejahatan Terhadap harta dalam Perstektif Hukum Islam, dalam Muhammad Amin Suma, dkk, Pidana Islam di Indonesia, Peluang, Prospek, dan Tantangan, Jakarta: Pustaka Firdaus. 
68 | Asy-Syari'ah Vol. 19 No. 1, Juni 2017 